\title{
Survey on College Students' Mobile English Learning Through APPs
}

\author{
Haiying Liu \\ Foreign Languages Department \\ Chongqing University of Arts and Sciences \\ Chongqing, China
}

\begin{abstract}
From the users' point of view, the survey obtained the first-hand data on users' learning content, duration, scene, terminal, purchasing habits of college mobile English learning through the questionnaire. On the basis of data analysis, the research described behavioral characteristics and tendencies of college students' mobile English learning through APPs, which provided the basis for decision-making for product content, user segmentation, technical mode, and pricing strategy on APPs for college students' mobile English learning.
\end{abstract}

\section{Keywords—college English; mobile learning; APP}

\section{INTRODUCTION}

When the first iPhone came out in 2007, few people were able to see its impact on education. However, in 2010, accompanied by the release of the iPad, smart phones have mushroomed in various models and brands. The lower cost of $3 \mathrm{G}, 4 \mathrm{G}$, and $\mathrm{WiFi}$ for mobile phones and the popularization of the Internet, you can say that mobile learning already has a material foundation. Mobile learning is also getting more attention, but the real hallmark of it to trigger the education revolution is the ability to develop a variety of APPs that are used on devices. Just as the researchers noted, when these APPs were released, educators found the potential for teaching with these devices was immediately available, including delivery opportunities for learning, convenience, collaborative learning, content generation and increased efficiency [1].

In the era of mobile connectivity, mobile APPs add new vitality to the network English teaching used to rely on PCs, this kind of the smart phones, as the tools, make dull language learning practice become interesting, efficient and convenient, as learners can learn at anytime, and in any places.

According to the research report on Internet mobile learning users in China in 2014, it was revealed that, on the mobile Internet learning, the survey of user group characteristics and behavioral preferences showed that the degree of satisfaction on foreign language learning APPs gained an absolute advantage, $89.3 \%$ ahead of other studies. The information communication in foreign language learning was connected with the natural properties of the mobile APPs, both of which have social functions. They can be intrinsically consistent, and be combined well. Therefore, the use of mobile APPs for English learning, especially the study of English words, will have broad prospects.

With continuous penetration of Internet in all fields of life, more close to the users, fragmentation learning of mobile learning is gaining popularity. With the rapid development of mobile intelligent terminal and campus wireless network, the campus mobile learning has the better technical condition and material foundation, in view of the rapid growth of college students' mobile learning needs.

Enter the "mobile learning" and "English" as the keywords in CNKI Full Text Search, the study of mobile English learning has been found in explosive growth in nearly five years. The proliferation of smart phones and the development of the mobile technology, the platform of mobile learning also changes rapidly from ordinary text messages, color letters, flying letters, easy communication with WeChat, to mobile APPs. Technicians continue to develop new techniques, while teachers continue to apply them and carry out the unremitting exploration in the field.

Most mobile education was mainly in language application, achieving $29.1 \%$. As for mobile learning content the popularity of foreign language learning made it ahead of other learning, reaching $89.3 \%$ as the absolute advantage. As for mobile learning user population distribution, college students accounted for the highest, reaching $32.8 \%$, far more than other user groups [2].

Universities are one of the important markets, for a long time, the development of campus mobile learning offers the opportunity, as well as the challenge to the market. Relevant research at present is mainly about mobile learning with the acquisition in qualitative research, while empirical research is relatively small. This paper, from the users' demanding perspective, through the questionnaire survey, obtained the first-hand data of the mobile users' earning content, learning length, learning scenes, mobile learning terminals, buying habits, etc. On the basis of the data analysis of college students' using behavioral characteristics and orientation of mobile application, the research explored the content of the college English learning in mobile application, and the segmentation of the users' group, technical scheme, which offered the policy basis.

In 2010, Shanghai TV University applied the "Mobile English learning system" to the test to send an English test 
daily to students based on text (SMS). And then the next day, the answer explanation and the teaching practice would be carried out. By the college English teaching team at Beijing Broadcasting and Television University (now Beijing Open University), in the year 2011, the "color letters" of the campus system adopted MMS to form the national network education, having achieved good results. Simultaneously, Beijing Open University also ran the platform to complement the "college English B" test for mobile tutoring[3].

Colleges and universities are also witnessing the benefits of English teaching of the new technology. Zhejiang Chinese Medicine University, by using WeChat, operated tutoring teaching on College English Test (Band 4) [4]. And Heilongjiang Agricultural Engineering Vocational College, based on WeChat's, had the practical English mobile learning application research [5]. In 2015, there were also schools, carried out the development and application of the game products, with the focus of the research remaining on the design and effect of mobile APPs on college students' English vocabulary learning [6].

In addition, foreign information technology used for language Learning practice is also processing further, from the "Computer Assisted Language Learning" to the "Mobile Assisted Language Learning". Que Xi at British Open University operated the research on teachers' design and user evaluation of Chinese language teaching in mobile application [7]. After pondering the literature, the author found that the researchers studying the moving English learning to transit from researches based on the original theoretical construction, the model design of the mobile platform, gradually to empirical research. In model design, Wang Wei, in his doctoral thesis, proposing the college English mobile learning MLMCE model in the context of teaching, started from English vocabulary teaching to listening, speaking and reading, etc. In teaching means, more and more colleges and universities are engaged in the development and application of mobile APPs [8].

However, when summarizing the results of English mobile learning, domestic scholars point out the research of mobile learning in China now occupies the theoretical research in a large proportion, but lacks innovation. As for the skill in the field of study, scholars are trying to introduce new technology. The key issues in mobile learning itself are difficult to solve. In the case of application and practice, some typical cases have been formed. However, it has not yet been fully summarized and experienced in the course of the experience [9]. Although some educators and students soon assimilated the new education technology to their practice, there is also the lack of the role of these education tools in the study. Golonka points out although in foreign language teaching, the topic of technical application already has a lot of publications, but the evidence for its effectiveness is still very limited. Therefore, we need to explore the problems on college students' mobile English learning through APPs [10].

\section{THE SURVEY}

\section{A. Respondents and Research Methods}

First of all, the author designed a "College students' mobile English learning questionnaire ". The questionnaire is divided into five parts, including basic information, mobile terminals, learning content, learning habits, and willingness and the behavior to pay for, with the single choice, multiple choice, and sorting, a total of three types of questions.

Next, the author questioned and recycled six departments. In the six departments, 6 classes were elected, including three liberal arts classes and three science classes. The questionnaire with more than $40 \%$ missing information is regarded as invalid. Only valid questionnaire data will be collected.

\section{B. Analysis of the Questionnaire Result}

Because part of the subjects are in multiple-choice questionnaire problems, so some data in the questionnaire survey are higher than the purveyed number of the participants.

1) College students' attitude towards English mobile applications: College students' attitude towards English mobile applications presented the high participation. The question, "Did you use English mobile application?" Respondents account for $91.3 \%$ who said "yes". Among them, $72.3 \%$ of respondents installed 1 2 English mobile applications. $18.4 \%$ of respondents installed 3 4 applications. Respondents installing 5 6 applications accounted for $4.8 \%$. Respondents installing more than six applications accounted for $4.5 \%$. Active users would be the persons, who, within two weeks, start English learning mobile applications. According to the questionnaire, active users are close to $91.7 \%$. The survey also presents the high expectations, as $93.4 \%$ of respondents have the optimistic prospects of English learning mobile application on campus.

And college students' satisfaction of mobile application development in English classes is very low, with $61.2 \%$ of respondents thinking mobile applications cannot meet the needs, and that the total of $25.4 \%$ basically or fully meets the requirements only.

2) The mobile phones are the core of the college students' mobile learning devices: Nearly $93 \%$ of the respondents chose mobile phones as the most-often-use mobile learning terminals. The intelligent cell machine operating systems, using iOS, accounted for about $2.2 \%$, Android, accounted for nearly 91.6\%, Windows Phone, Symbian, and other system, accounted for about $6.2 \%$.

3) The scenarios and time-length of college students' using English mobile applications: As for the distribution of college students using English mobile applications, the top two are in class and self-study, which can be seen as a college student's daily learning time. The time for lining or waiting, taking traffic tools, time before going to sleep etc. are all the fragments, although these scenes rank behind, but 
the total of them for college students to use various pieces of time are far more than other learning time.

4) The deficiency existing in college English mobile applications: At present, the deficiency existing in college English mobile application is mainly the product quality and content. The quality of education category are various. And the developers are multifarious, with the good and the bad intermingling. As capital began to enter the market in great quantities, in a short time, a large number of identical, the low-quality applications emerged. But in terms of content, the presses controlling premium content are cautious in terms of content, and most small developers with the lack of content resources, produced a large number of products in the poor quality.

5) Students' urgent need of the types of English learning mobile applications: Among the purposes of college students' use English learning mobile applications, "Helpful in the exam" (50.5\%), "to improve your English to enhance employment"(25.3\%), " personal interests" (16.29\%), the "other"(27.31\%). "Helpful in the exam" ranked first, which explains why the urgent need of application type of college students is the exam and tutoring. The exam and tutoring category in the market at present is about the exams, with the content, mostly the real items of the real exams or ones of the model tests with attached explanation. Products lack variety, which have the low-quality content, therefore plagiarism phenomenon is serious.

Products put forwards high demands on the education background, capability and technology of developers, who should not only control the quality, but also be familiar with college English teaching, to provide valid learning services, and will have sufficient technical ability to achieve reasonable presentation of contents at the mobile end. In the survey, college English classroom APPs form a complete set, ranked second in the most-needed product type. However, such products have the small number in the market. The dictionaries and listening/speaking are already hot in training class segment. Browsing the APP store and android market, you will find that dictionaries APP and listening/speaking training class applications occupied more than half of the proportion. In the survey, respectively the two ranked the second. Therefore the three are the most needed products.

6) Distribution of the download channels of college students' English learning mobile applications: Mainstream APP stores are the main channel for college students to download English class mobile applications. Star products still lack markets, which have not formed obvious brand appeal and rely more on the products themselves. And the mainstream APP stores' download ranking and editors' recommendations are the main factors affecting college students' tend to choose mobile applications.

With the continuous development of mobile learning, more and more college students focus on mobile application market, and product-related information through product website and search engine actively.
7) College students' willingness to pay for English mobile applications: College students' willingness to pay for English mobile applications is not high, as only about $13 \%$ of respondents are willing to pay. And actual-paying accounts rather low, because only about 7\% among the investigated objects in willingness to pay. In terms of amount, $100 \sim 300$ yuan is accepted as the most.

\section{The DEVELOPMENT STRATEGY OF COLLEGE ENGLISH MOBILE LEARNING APPS}

\section{A. College English Mobile Learning Production System Should Be Built}

At mobile application market, there is no clear business mode, the development of mobile applications is still at the the exploring stage. We had better build a reasonable structure of assembly line of the college English class mobile applications as soon as possible. This is not to say that applications should only pursuit the quantity, but the system is only in the development to meet the needs of the users and should be able to be used in the process of application development through innovation mode. We should establish and perfect a set of management rules and regulations, improve staff in the new work mode and adapt the processing ability, perfect marketing modes and set up application sales platform, and application and brand influence as soon as possible, which is suitable to the society and business modes. That is to say, first, as mentioned earlier, many dictionaries APPs and listening/speaking training classes APPs, which have occupied more than half shares, have single function with poor content. Applications in high quality on exam tutoring classes and college English classroom APPs are not enough, so the two types of applications should be first focused on.

\section{B. The Core Competitive Ability Is Always the Profound Content}

The good and bad of the current applications in mobile education are intermingling. Therefore, truly valuable content to customers is the key to a mobile application developer to win the users. In college education content system, authority requirements are extremely high, compared with the mobile application market, the core competitive ability is always a profound content accumulation and strong editing planning ability. On one hand, compared with books and other digital publications, the mobile application has characteristics of being fragmented, in media, fast updated. Matching content production mechanism should be established as soon as possible. On the other hand, as for mobile learning, college teachers remain at the head of the exploration practice. Classes with the new teaching modes and ideas become, in college English teaching, the major spots of the reform. Teachers at colleges and universities are not only the important users, simultaneously, the leading authors. Producers should closely cooperate with teachers at colleges and universities, especially active young and middle-aged teachers in practice in English teaching reform. 


\section{ACKNOWLEDGMENTS}

First of all, I would like to express my sincere thanks to my colleagues, who offered me great help in my research. Then, I will give my great appreciation to all students who were involved in the study. Finally, I share some splendid ideas with the authors of these references. Therefore, I extend my sincere thanks to them all.

\section{REFERENCES}

[1] D. Murphy, "Post-pc devices: A summary of early iPad technology adoption in tertiary environments," E-Journal of Business Education \& Scholarship of Teaching, Retrieved from http://www.ejbest.org/upload/ejbest_Murphy_2011_1.pdf, 2011.

[2] Aimei Consulting Agency: "Report on Chinese mobile education market in 2015-2016", http://www. iimedia.cn/40589.html, 2016-0127.

[3] Q. Lin, "Empirical research on mobile teaching based on the flying interactive platform ," Journal of Guangxi Broadcasting and TV University, vol. 1, 2015, pp. 34-37.

[4] Y. Yin, "The study of mobile learning in college English(Band Four) under the guidance of micro-learning theory - an empirical study based on the WeChat public platform ," Technology Horizon,vol. 2, 2013, pp. 56-57.

[5] H. Hui, "Research on the applications in practical English mobile learning based on WeChat," Technology Outlook, vol. 3, 2015, pp. 296-297.

[6] Y. Su, "The development and application of the English word games of mobile learning - Take the "happy farm" game as an example ," Foreign Language Teaching, vol. 9, 2015, pp. 30-35.

[7] F. Rosell-aguilar, and Q. Kan, "Design and user evaluation of a mobile application to teach Chinese characters ," The JALT CALL Journal, vol. 11, 2016, pp. 19-40.

[8] W. Wang, "Research on the mobile learning system mode," Changchun: Northeast Normal University, Doctoral Dissertation, 2011.

[9] E.Golonka, A. Bowles, and D. Richardson, "Technologies for foreign language learning: a review of technology types and their effectiveness," Computer-assisted Language Learning, vol. 1, 2016, pp. 70-105. 